\title{
Riverbed sediments buffer phosphorus concentrations downstream of sewage treatment works across the River Wensum catchment, UK
}

\author{
Ellie J. Roberts ${ }^{1} \cdot$ Richard J. Cooper ${ }^{1}$ \\ Received: 10 November 2017 / Accepted: 29 January 2018 / Published online: 15 February 2018 \\ (C) The Author(s) 2018. This article is an open access publication
}

\begin{abstract}
Purpose Wastewater effluent discharged into rivers from sewage treatment works (STWs) represents one of the most important point sources of soluble reactive phosphorus (SRP) pollution and is a major driver of freshwater eutrophication. In this study, we assess the ability of riverbed sediments to act as a self-regulating buffering system to reduce SRP dissolved in the water column downstream of STW outflows.

Materials and methods River water and riverbed sediment samples were collected from ten tributary outlets across the River Wensum catchment, Norfolk, UK, at monthly intervals between July and October 2016, such that 40 sediment and 40 water samples were collected in total. Of these locations, five were located downstream of STWs and five were on tributaries without STWs. Dissolved SRP concentrations were analysed, and the equilibrium phosphorus concentration $\left(\mathrm{EPC}_{0}\right)$ of each sediment sample was measured to determine whether riverbed sediments were acting as net sources or sinks of SRP.

Results and discussion The mean SRP concentration downstream of STWs $\left(382 \mu \mathrm{g} \mathrm{P} \mathrm{L}{ }^{-1}\right)$ was double that of sites without a STW $\left(185 \mu \mathrm{g} \mathrm{P} \mathrm{L}^{-1}\right)$, whilst the mean $\mathrm{EPC}_{0}$ for effluent impacted sites $\left(105 \mu \mathrm{g} \mathrm{P} \mathrm{L}{ }^{-1}\right)$ was $70 \%$ higher than that recorded at unaffected sites $\left(62 \mu \mathrm{g} \mathrm{P} \mathrm{L}{ }^{-1}\right)$. Regardless of STW influence, riverbed sediments across all ten sites almost always acted as net sinks for SRP from the overlying water column. This was particularly true at sites downstream of STWs which displayed enhanced potential to buffer the river against increases in SRP released in sewage effluent.

Conclusions Despite $\mathrm{EPC}_{0}$ values revealing riverbed sediments were consistently acting as sinks for SRP, elevated SRP concentrations downstream of STWs clearly demonstrate the sediments have insufficient SRP sorption capacity to completely buffer the river against effluent discharge. Consequently, SRP concentrations across the catchment continue to exceed recommended standards for good chemical status, thus emphasising the need for enhanced mitigation efforts at STWs to minimise riverine phosphorus loading.
\end{abstract}

Keywords Equilibrium phosphorus concentration · Eutrophication - Sediment - Soluble reactive phosphorus · Sorption · Wastewater

\section{Introduction}

Since the early twentieth century, rapid population growth, intensification of agriculture and extensive urbanisation have

Responsible editor: Marcel van der Perk

Electronic supplementary material The online version of this article (https://doi.org/10.1007/s11368-018-1939-x) contains supplementary material, which is available to authorized users.

Richard J. Cooper

Richard.J.Cooper@uea.ac.uk

1 School of Environmental Sciences, University of East Anglia, Norwich Research Park, Norwich NR4 7TJ, UK led to widespread phosphorus (P) enrichment of aquatic environments (Cordell et al. 2009) resulting in an array of detrimental economic (Pretty et al. 2003) and ecological impacts (Hilton et al. 2006; Jarive et al., 2018). As a naturally limiting nutrient of plant growth in waterbodies, P-enrichment fuels blooms of phytoplankton, periphyton and neuro-toxin secreting cyanobacteria colonies, which can dramatically lower species diversity and lead to a fundamental breakdown of ecosystem functioning (Smith et al. 1999).

Wastewater effluent discharged into rivers from sewage treatment works (STWs) represents one of the most important point sources of $\mathrm{P}$ pollution and is a major driver of freshwater eutrophication (Jarvie et al. 2006). STWs discharge effluent continuously with high-P concentrations and because the 
majority (70-90\%) of the $\mathrm{P}$ is released as biologically available soluble reactive phosphorus (SRP), it carries increased risk of initiating deleterious changes in ecological communities (Demars et al. 2005; Edwards and Withers 2008). Consequently, under the EU Urban Wastewater Directive (91/271/EC), STWs serving a population of 10,000100,000 people have water quality restrictions set at $2 \mathrm{mg} \mathrm{P} \mathrm{L}{ }^{-1}$ for effluent discharging into a surface watercourse, with this decreasing to $1 \mathrm{mg} \mathrm{P} \mathrm{L}{ }^{-1}$ for facilities serving $>100,000$ people. However, smaller facilities $(<$ 10,000 people) have no legal requirement to meet such targets and $\mathrm{P}$ concentrations in effluent discharges of up to $20 \mathrm{mg} \mathrm{P} \mathrm{L}^{-1}$ have been recorded (Neal et al. 2005; Jarvie et al. 2006; Withers and Jarvie 2008). Previous water quality monitoring studies have therefore observed increases in dissolved $\mathrm{P}$ concentrations of $>600 \%$ downstream of STW outflows (House and Denison 2002; Demars and Harper 2005), with concentration orders of magnitude greater than the $40-120 \mu \mathrm{g} \mathrm{P} \mathrm{L}^{-1}$ concentration recommended under the EU Water Framework Directive (2000/60/EC) to achieve 'good' ecological and chemical status.

Through various physical, chemical and biological processes, river systems have the internal capacity to cycle $\mathrm{P}$ between the sediments on the riverbed and the overlying water column and to transform $\mathrm{P}$ between organic, inorganic, particulate and dissolved forms (Jarvie et al. 2005). This cycling includes biotic and abiotic transformations related to $\mathrm{P}$ uptake/release, adsorption/desorption, precipitation/dissolution and advection/diffusion (Withers and Jarvie 2008). Importantly, this P cycling can create a self-regulating buffering system whereby riverbed sediments act to buffer SRP dissolved in the water column downstream of STWs (Wang and $\mathrm{Li}$ 2010). In this respect, the Equilibrium Phosphorus Concentration $\left(\mathrm{EPC}_{0}\right)$ is a measure to determine whether riverbed sediments are acting as net sources or sinks of SRP. The $\mathrm{EPC}_{0}$ is defined as the concentration of SRP in solution which, when placed in contact with sediment, produces no net sorption or desorption of SRP over a period of $24 \mathrm{~h}$ (House et al. 1995; House and Denison 2000). When SRP > $\mathrm{EPC}_{0}$, the sediment has the potential to take up SRP from the water column and when $\mathrm{SRP}<\mathrm{EPC}_{0}$, the sediment has the potential to release SRP into the water column (PalmerFelgate et al. 2009). It is this differential between the $\mathrm{EPC}_{0}$ of the sediment and the SRP concentration of the bed sediment-water interface layer (defined to a depth of $0.1 \mathrm{~m}$ ) that determines the uptake or release of SRP from riverbed sediments (Jarvie et al. 2005).

Whether riverbed sediment acts as a source or a sink for SRP is primarily related to the redox conditions and physicochemical properties of the sediment as this determines the bed sediment P-sorption behaviour (Palmer-Felgate et al. 2009). In particular, the particle size, mineralogy and the concentration of exchangeable phosphate already sorbed onto the sediment surface are key factors which influence the speciation of $\mathrm{P}$ in the sediment, as well as the potential for SRP exchange across the sediment-water interface (Stone et al. 1995; Zhang and Huang 2007).

Due to the continuous nature of STW effluent discharge, P concentrations downstream of STWs tend to display a highly seasonal pattern with higher concentrations during the summer low flows and lower concentrations during winter high flows due to dilution, thus causing $\mathrm{P}$ concentrations to peak during ecologically sensitive summer season when eutrophication risk is greatest (Cooper et al. 2002; Withers and Jarvie 2008; Bowes et al. 2012). The sorption and storage of SRP by riverbed sediments downstream of STWs can therefore play a vital role in reducing eutrophication risk during the ecologically sensitive low-flow summer period (Jarvie et al. 2006). However, because riverbed sediment chemistry is a major controlling factor on the chemistry of the overlying waterbody, deposition of P-rich fines can also act as a localised source of SRP if concentrations are greater than in the overlying waterbody or if sediments become entrained by biotic mixing and storm events (Jarvie et al. 2005; van der Perk et al. 2007). Increased $P$ concentrations on the riverbed can also fuel excessive growth of macrophytes and benthic algae which are able to extract nutrients directly from the sediment rather than relying on dissolved SRP (Hilton et al. 2006). Understanding P cycling and the balance of these processes within ecosystems is therefore an important aspect of $\mathrm{P}$ transport which should be adequately represented within catchment management plans. Research into $\mathrm{EPC}_{0}$ values can assist by providing a clearer insight into abiotic cycling processes related to $\mathrm{P}$ uptake/release within fluvial systems.

The aim of this study was to investigate how the presence of STWs influences the $\mathrm{EPC}_{0}$ of riverbed sediments and dissolved SRP concentrations during the summer and early autumn low-flow periods of high-eutrophication risk in the River Wensum, UK - a river with multiple conservation designations suffering from elevated $\mathrm{P}$ concentrations and containing a large number of STWs. The main objectives were as follows:

(i) Determine if riverbed sediments are effective at buffering dissolved SRP downstream of STWs;

(ii) Contrast tributaries with and without a STW to assess where sediments are acting as net sources or sinks for P;

(iii) Assess whether the ability of sediment to uptake excess $\mathrm{P}$ varies temporally.

To our knowledge, there have been no direct measurements of riverbed sediment $\mathrm{EPC}_{0}$ values in the River Wensum during the past decade and it is envisaged that this study will assist in providing an improved management plan for nutrient enrichment across the wider Wensum catchment. 


\section{Materials and methods}

\subsection{Study location}

The River Wensum, Norfolk, UK, is a 78-km-length groundwater-dominated lowland (source $=75 \mathrm{~m}$ above sea level) calcareous river that drains an area of $660 \mathrm{~km}^{2}$ and has a mean annual discharge of $4.1 \mathrm{~m}^{3} \mathrm{~s}^{-1}$ near its outlet (Fig. 1). The river is designated a Site of Special Scientific Interest (SSSI) and a European Special Area of Conservation (SAC) in recognition of it being one of the best examples of a lowland calcareous river in the world due to the diversity of its internationally important flora and invertebrate fauna. However, $99.4 \%$ of the river habitat is considered to be in an unfavourable and declining state due to poor morphology (e.g. channelized, disconnected from the floodplain), sedimentation and eutrophication, whilst $27 \%$ of waterbodies across the catchment are at risk of failing $P$ standards (Sear et al. 2006). There are 21 STWs across the catchment serving a population of $c .57,000$ people of which seven of these have tertiary P stripping technologies installed to reduce nutrient discharges (Evans 2012). Previous modelling studies using SAGIS and SEPARATE have estimated STWs are responsible for 26$47 \%$ of $\mathrm{P}$ in the River Wensum, compared with $29-40 \%$ derived from agriculture and $20-32 \%$ from other sources including urban runoff, storm tanks, atmospheric deposition and riverbank erosion (Natural England 2015). In addition, there are an estimated 1863 properties off mains sewage served by domestic septic tank systems, estimated to contribute a further 2-4\% of the annual P load (Natural England 2015).

The catchment is underlain by Cretaceous White Chalk bedrock which is unconfined in the upper catchment and along sections of the river valley where the baseflow index (BFI) is 0.7-0.9. Over much of the rest of the catchment, the Chalk is confined by superficial deposits of Mid-Pleistocene diamicton glacial tills principally comprising chalky, flint-rich boulder clays of the Sheringham Cliffs $(\sim 0.2-10 \mathrm{~m}$ depth) and Lowestoft $(\sim 10-20 \mathrm{~m}$ depth) formations (Fig. S1, Electronic Supplementary Material). These are interspersed with layers of glaciofluvial and glaciolacustrine sands and gravels where the BFI is $0.5-0.7$. Within the river valley, Holocene-age alluvium and river terrace deposits are present (Hiscock et al. 1996; Lewis 2014). Surface soils across the catchment range from low-permeability clay loams and sandy peats, to free draining sandy loams (Fig. S2, Electronic Supplementary Material). Arable agriculture (wheat, barley, sugar beet, oilseed rape) dominates land use $(63 \%)$ with the remainder comprising 19\% improved grassland, 9\% mixed woodland, 5\% unimproved grassland and $4 \%$ urban. The mean annual temperature is $10.1{ }^{\circ} \mathrm{C}$ and the mean annual rainfall total is $674 \mathrm{~mm}$ (1981-2010) (Met Office 2017).

\subsection{Field campaign}

River water and riverbed sediment samples were collected from ten tributary outlets across the catchment (Fig. 1) at monthly intervals between July and October 2016, such that 40 sediment and 40 water samples were collected in total during the field campaign. Of these ten locations, five were located downstream of STWs (sites 1, 6, 8, 14, 15) and five were on tributaries without a STW (sites 2, 9, 16, 20, 21). Sites influenced by STWs were situated $>500 \mathrm{~m}$ downstream of the facility to ensure the effluent discharge would be well mixed by the time it reached the sampling location. Riverbed sediments $(\sim 500 \mathrm{~g})$ were collected from the upper $10 \mathrm{~cm}$ of the riverbed using a trowel and were sieved down to $2 \mathrm{~mm}$ on site to remove coarse sands and gravels which have limited $\mathrm{P}$ storage/release potential. River water was grab-sampled from the centre of the channel at $\sim 0.5 \times$ river depth in $1 \mathrm{~L}$ polypropylene bottles. All samples were returned to cold storage $\left(4^{\circ} \mathrm{C}\right)$ within $4 \mathrm{~h}$ to minimise biological degradation, and all analysis was completed within 7 days. Samples collected in July $\left(1.50 \mathrm{~m}^{3} \mathrm{~s}^{-1}\right)$, August $\left(1.20 \mathrm{~m}^{3} \mathrm{~s}^{-1}\right)$ and October $\left(1.46 \mathrm{~m}^{3} \mathrm{~s}^{-1}\right)$ were taken under baseflow conditions (based on the hydrograph of the site 8 gauging station) with limited rainfall $(4,7$ and $14 \mathrm{~mm}$, respectively) occurring in the preceding 5 days (Fig. 2). Higher discharges $\left(1.83 \mathrm{~m}^{3} \mathrm{~s}^{-1}\right)$ were observed during September reflecting higher rainfall totals $(35 \mathrm{~mm})$ in the 5 days before sampling.

\subsection{Laboratory analysis}

Riverbed sediment $\mathrm{EPC}_{0}$ values were derived following the methods of Jarvie et al. (2005). Approximately $2 \mathrm{~g}$ of each wet sediment sample was oven-dried $\left(110{ }^{\circ} \mathrm{C}\right)$ for $18 \mathrm{~h}$ and weighed to determine water content. For each sediment subsample, wet sediment (equivalent to $0.5 \mathrm{~g}$ dry weight) was added into six $250 \mathrm{~mL}$ volume centrifuge tubes along with $200 \mathrm{~mL}$ of chilled $\mathrm{CaCl}_{2}$ solution (220 mg L $\mathrm{m}^{-1}$ ). This solution was chosen to simulate similar calcium concentrations and conductivity to the calcareous waters of the River Wensum $\left(\sim 120 \mathrm{mg} \mathrm{Ca} \mathrm{L}^{-1}\right)$. The six centrifuge tubes were individually spiked with a phosphate standard $\left(\mathrm{KH}_{2} \mathrm{PO}_{4}\right)$ to give concentrations of $0,50,100$, 250, 500 and $1000 \mu \mathrm{g} \mathrm{P} \mathrm{L}^{-1}$ and shaken in an incubated $\left(10^{\circ} \mathrm{C}\right)$ orbital shaker $(150 \mathrm{rpm}, 24 \mathrm{~h})$ to ensure all sediment was in contact with the solution. After shaking, samples were centrifuged $(6000 \mathrm{rpm}, 5 \mathrm{~min})$ and the supernatant extracted and filtered through a $0.45-\mu \mathrm{m}$ syringe filter. Fifty milliliter of each filtered sample was added to separate $100 \mathrm{~mL}$ conical flasks to which $5 \mathrm{~mL}$ of mixed reagent (ammonium molybdate, sulphuric acid, ascorbic acid, potassium antimonyl tartrate) was added. After $30 \mathrm{~min}, 2 \mathrm{~mL}$ of each sample was transferred to cuvettes and analysed 


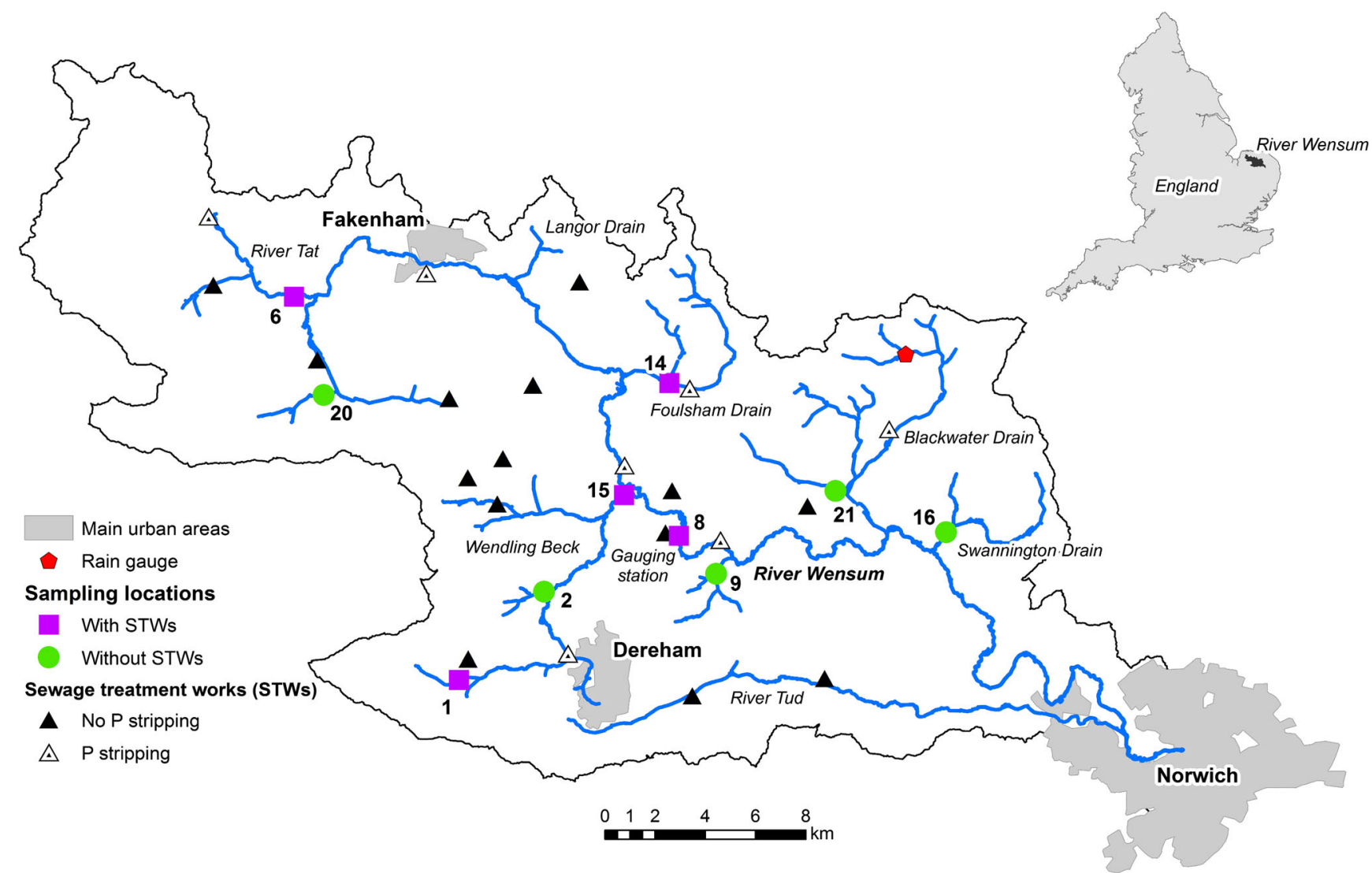

Fig. 1 Distribution of sampling locations and sewage treatment works across the River Wensum catchment, Norfolk, UK

colorimetrically to determine SRP concentration using a spectrophotometer $(885 \mathrm{~nm})$. River water samples were similarly filtered through a $0.45-\mu \mathrm{m}$ syringe filter and $50 \mathrm{~mL}$ added to $5 \mathrm{~mL}$ of mixed reagent prior to analysing colorimetrically for SRP concentration.

\section{4 $\mathrm{EPC}_{0}$ calculations}

The $\mathrm{EPC}_{0}$ was derived by first calculating the change in SRP concentration $\left(\Delta \mathrm{C}\right.$ in $\left.\mu \mathrm{g} \mathrm{P} \mathrm{L}{ }^{-1}\right)$ of the solution after $24 \mathrm{~h}$ incubation with the riverbed sediment whilst correcting for any differences in sediment mass and solution volume (Eq. (1)):

$\Delta C=\frac{V}{m} C_{0}-C_{24}$

where $V$ is the total volume of the solution (L); $m$ is the mass of dry sediment $(\mathrm{g}) ; C_{0}$ is the concentration of the SRP spikes $\left(\mu \mathrm{g} \mathrm{P} \mathrm{L}^{-1}\right.$ ) at time zero and $C_{24}$ is the SRP concentration of the solution after being shaken for $24 \mathrm{~h}\left(\mu \mathrm{g} \mathrm{P} \mathrm{L}^{-1}\right) . \Delta \mathrm{C}$ was then
Fig. 2 Annual hydrograph for the River Wensum recorded at the Swanton Morley gauging station (sampling site 8) during the period 1969-2016 (CEH 2018). Precipitation record is for 2016. Vertical lines refer to sampling dates in 2016

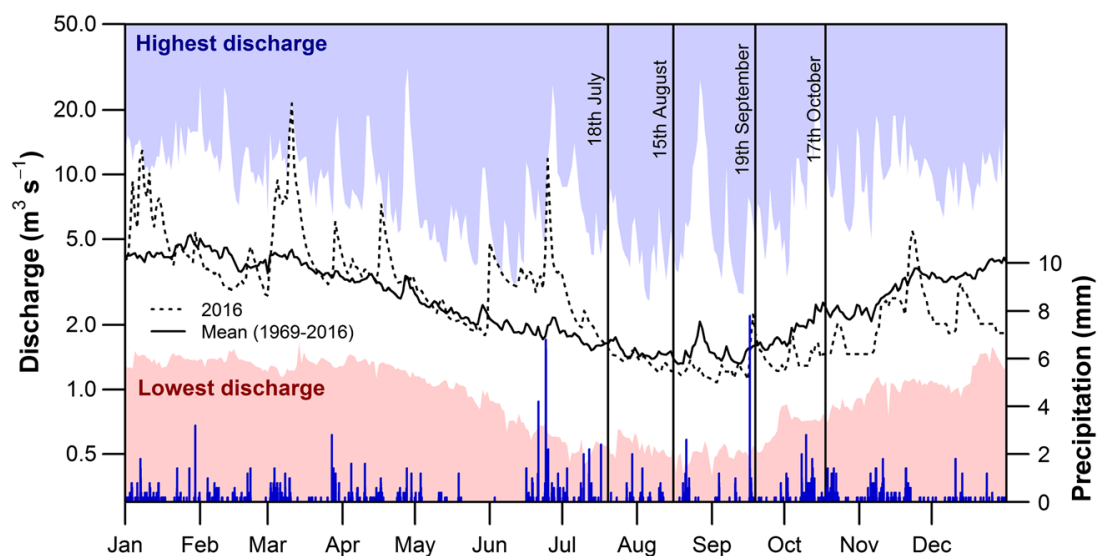




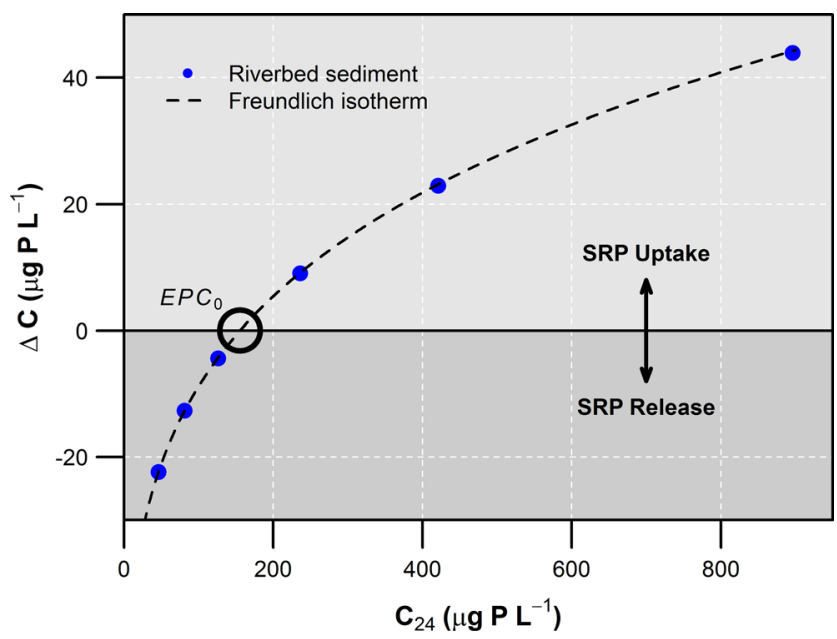

Fig. 3 Example Freundlich isotherm plot for Wensum site 2 used to estimate the equilibrium phosphorus concentration $\left(\mathrm{EPC}_{0}\right)$ of riverbed sediment

plotted against the SRP concentration in solution after $24 \mathrm{~h}$ $\left(C_{24}\right)$, and the data points fitted with a non-linear least squares Freundlich isotherm (Eq. (2); House and Denison 2000), which yields the $\mathrm{EPC}_{0}$ where it intercepts the $\mathrm{x}$-axis (Fig. 3):

$$
\Delta C=K_{\mathrm{f}} C_{24^{\frac{1}{n}}}
$$

where $K_{\mathrm{f}}$ is a constant related to the affinity of sorption and $n$ is the Freundlich isotherm constant.

\section{Results and discussion}

\subsection{Impact of STWs on dissolved P concentrations}

Concentrations of dissolved SRP were high across the River Wensum catchment, with mean concentrations for all ten sampling locations exceeding the recommended $40-120 \mu \mathrm{g} \mathrm{P} \mathrm{L}^{-1}$ standard for good chemical status (Table 1). The highest and lowest SRP concentrations were recorded at site 1 $\left(1136 \mu \mathrm{g} \mathrm{P} \mathrm{L}^{-1}\right)$ and site $9\left(46 \mu \mathrm{g} \mathrm{P} \mathrm{L}^{-1}\right)$, respectively, both in October 2016. The overall mean SRP concentration for all sites combined was $284 \mu \mathrm{g} \mathrm{P} \mathrm{L}^{-1}\left(\sigma=193 \mu \mathrm{g} \mathrm{P} \mathrm{L}^{-1}\right)$, but there were pronounced statistically significant differences $(t$ test, $p<0.05$ ) between sites depending on whether they were impacted by effluent discharges from STWs (Fig. 4). Mean SRP concentrations for individual sites downstream of STWs ranged from 278 to $647 \mu \mathrm{g} \mathrm{P} \mathrm{L}^{-1}$, whilst they ranged from 124 to $247 \mu \mathrm{g} \mathrm{P} \mathrm{L}^{-1}$ at sites without a STW, meaning that all sites impacted by STW outflows had higher SRP concentrations than unaffected sites. However, there was no significant relationship ( $p=0.269 ; R^{2}=0.02$ ) between SRP concentration and the distance downstream from the STW outflows. The overall mean SRP for impacted sites $\left(382 \mu \mathrm{g} \mathrm{P} \mathrm{L}^{-1}\right)$ was double that of unaffected sites $\left(185 \mu \mathrm{g} \mathrm{P} \mathrm{L}^{-1}\right)$.
To put these values in context with the natural background $\mathrm{P}$ concentrations for this region, a previous study on the neighbouring, hydrochemically similar, River Bure recorded a mean concentration of just $4 \mu \mathrm{g} \mathrm{SRP} \mathrm{L}{ }^{-1}$ on a section of the river which flowed through an entirely wooded sub-catchment without point or diffuse source P inputs from STWs or agriculture (Moss et al. 1988). Additionally, groundwater analysed from $6,12,15$ and $50 \mathrm{~m}$ depth boreholes drilled in the Blackwater Drain sub-catchment of the River Wensum had mean total P concentrations of $<10 \mu \mathrm{g} \mathrm{SRP} \mathrm{L}^{-1}$ (Lewis 2014).

Although the largest two STWs (Dereham and Fakenham) in the River Wensum catchment have P stripping facilities installed, such technology is absent from the 14 smaller rural STWs as it is not considered cost-effective to install for works severing relatively small populations (Bewes et al. 2012). However, these results clearly demonstrate that STWs are significantly elevating SRP concentrations above the levels observed in unaffected tributaries and are adding to diffuse $P$ inputs from the surrounding agricultural land. Without the installation of $\mathrm{P}$ removal technologies (e.g. chemical precipitation, enhanced biological removal) at more STWs, P enrichment is likely to be amplified over the coming decades by an increasing population resulting in greater sewage effluent discharge across the Wensum catchment.

\subsection{Riverbed sediments as sources or sinks of $P$}

The $\mathrm{EPC}_{0}$ values varied widely across the sites from a low of $18 \mu \mathrm{g} \mathrm{P} \mathrm{L}^{-1}$ at site 9 in September 2016, to a high of $189 \mu \mathrm{g} \mathrm{P} \mathrm{L}^{-1}$ at site 20 in August (Table 1). The overall mean $\mathrm{EPC}_{0}$ value for all sites combined was $81 \mu \mathrm{g} \mathrm{P} \mathrm{L}{ }^{-1}(\sigma=$ $54 \mu \mathrm{g} \mathrm{P} \mathrm{L}^{-1}$ ), but as with SRP concentrations, there were statistically significant differences $(t$ test, $p<0.05)$ between sampling locations depending on the presence or absence of STWs (Fig. 4). The mean $\mathrm{EPC}_{0}$ for individual sites downstream of STWs ranged from 74 to $147 \mu \mathrm{g} \mathrm{L} \mathrm{L}^{-1}$, whilst sites without a STW ranged from 32 to $117 \mu \mathrm{g} \mathrm{P} \mathrm{L}^{-1}$. The overall mean $\mathrm{EPC}_{0}$ for STW impacted sites $\left(105 \mu \mathrm{g} \mathrm{P} \mathrm{L}^{-1}\right)$ was $70 \%$ higher than that of unaffected sites $\left(62 \mu \mathrm{g} \mathrm{P} \mathrm{L}^{-1}\right)$, likely reflecting the deposition of P-rich fines on the riverbed downstream of STWs. There was no significant relationship ( $p=$ 0.06; $R^{2}=0.17$ ) between $\mathrm{EPC}_{0}$ and the distance downstream from the STW outflows.

Note, for site 1, $\mathrm{EPC}_{0}$ values could not be calculated as all $\Delta C$ values were negative and the Freundlich isotherm never intercepted the $\mathrm{X}$-axis. This, combined with the very high SRP concentrations recorded at this site, suggests that the sediments here were fully saturated with P and were likely releasing SRP into the water column even at high-spike concentrations (i.e. $1000 \mu \mathrm{g} \mathrm{P} \mathrm{L}^{-1}$ ). Visual observations indicate this was likely due to the riverbed at site 1 being composed of a much higher proportion of coarse gravel and cobbles with 


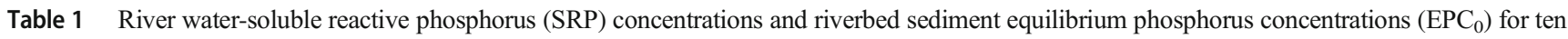
sites across the River Wensum catchment with or without a sewage treatment works (STW) for the period of July-October 2016

\begin{tabular}{|c|c|c|c|c|c|c|c|c|c|c|c|c|}
\hline \multirow[t]{2}{*}{ STWs } & \multirow{2}{*}{ Site } & \multirow{2}{*}{$\begin{array}{l}\text { Distance from } \\
\text { STW } \\
(\mathrm{km})\end{array}$} & \multicolumn{2}{|l|}{ July } & \multicolumn{2}{|l|}{ August } & \multicolumn{2}{|c|}{ September } & \multicolumn{2}{|l|}{ October } & \multicolumn{2}{|l|}{ Mean } \\
\hline & & & $\begin{array}{l}\mathrm{SRP} \\
\left(\mu \mathrm{g} \mathrm{L}^{-1}\right)\end{array}$ & $\begin{array}{l}\mathrm{EPC}_{0} \\
\left(\mu \mathrm{g} \mathrm{L}^{-1}\right)\end{array}$ & $\begin{array}{l}\text { SRP } \\
\left(\mu \mathrm{g} \mathrm{L}^{-1}\right)\end{array}$ & $\begin{array}{l}\mathrm{EPC}_{0} \\
\left(\mu \mathrm{g} \mathrm{L}^{-1}\right)\end{array}$ & $\begin{array}{l}\text { SRP } \\
\left(\mu \mathrm{g} \mathrm{L}^{-1}\right)\end{array}$ & $\begin{array}{l}\mathrm{EPC}_{0} \\
\left(\mu \mathrm{g} \mathrm{L}^{-1}\right)\end{array}$ & $\begin{array}{l}\text { SRP } \\
\left(\mu \mathrm{g} \mathrm{L}^{-1}\right)\end{array}$ & $\begin{array}{l}\mathrm{EPC}_{0} \\
\left(\mu \mathrm{g} \mathrm{L}^{-1}\right)\end{array}$ & $\begin{array}{l}\text { SRP } \\
\left(\mu \mathrm{g} \mathrm{L}^{-1}\right)\end{array}$ & $\begin{array}{l}\mathrm{EPC}_{0} \\
\left(\mu \mathrm{g} \mathrm{L}^{-1}\right)\end{array}$ \\
\hline \multirow[t]{5}{*}{ With } & 1 & 0.7 & 340 & - & 540 & - & 571 & - & 1136 & - & 647 & - \\
\hline & 6 & 4.0 & 290 & 80 & 245 & 116 & 376 & 142 & 201 & 61 & 278 & 100 \\
\hline & 8 & 0.6 & 215 & 164 & 245 & 103 & 471 & 56 & 291 & 66 & 305 & 97 \\
\hline & 14 & 0.9 & 360 & 45 & 335 & 94 & 411 & 99 & 276 & 57 & 345 & 74 \\
\hline & 15 & 5.5 & 255 & 179 & 125 & 61 & 651 & 173 & 341 & 177 & 335 & 147 \\
\hline Mean & & & 286 & 117 & 298 & 94 & 496 & 118 & 449 & 90 & 382 & 105 \\
\hline \multirow[t]{5}{*}{ Without } & 2 & - & 220 & 32 & 219 & 75 & 276 & 156 & 275 & 67 & 247 & 83 \\
\hline & 9 & - & 115 & 28 & 230 & 25 & 106 & 18 & 46 & 56 & 124 & 32 \\
\hline & 16 & - & 135 & 62 & 130 & 25 & 181 & 57 & 61 & 32 & 127 & 44 \\
\hline & 20 & - & 175 & 53 & 305 & 189 & 216 & 185 & 186 & 40 & 223 & 117 \\
\hline & 21 & - & 175 & 41 & 110 & 23 & 366 & 21 & 171 & 44 & 205 & 32 \\
\hline Mean & & & 164 & 46 & 199 & 66 & 229 & 70 & 150 & 43 & 185 & 62 \\
\hline
\end{tabular}

low-P sorption capacity than observed at the other sampling sites (Fig. S3, Electronic Supplementary Material).

Plotting SRP against $\mathrm{EPC}_{0}$ (Fig. 5) reveals that riverbed sediments at all ten sites, regardless of STW influence, were almost always acting as a sink for SRP from the overlying water column, with SRP concentrations consistently greater than the sediment $\mathrm{EPC}_{0}$ values. The only exception to this was during October at site 9 when the $\mathrm{EPC}_{0}\left(56 \mu \mathrm{g} \mathrm{P} \mathrm{L}{ }^{-1}\right)$ was marginally higher than the river water SRP concentration (46 $\mu \mathrm{g} \mathrm{P} \mathrm{L}^{-1}$ ). The residual concentration (i.e. SRP- $-\mathrm{EPC}_{0}$ ) revealed sites without a STW were significantly $(p<0.05)$ closer to the $1: 1$ equilibrium line (mean residual $=$ $124 \mu \mathrm{g} \mathrm{P} \mathrm{L}^{-1} ; \sigma=74 \mu \mathrm{g} \mathrm{P} \mathrm{L}^{-1}$ ) than STW-impacted sites (mean residual $=211 \mu \mathrm{g} \mathrm{P} \mathrm{L}^{-1} ; \sigma=119 \mu \mathrm{g} \mathrm{P} \mathrm{L}^{-1}$ ). This means that even though locations downstream of STWs had significantly higher SRP and $\mathrm{EPC}_{0}$ concentrations, the increase in $\mathrm{EPC}_{0}(+70 \%)$ relative to non-impacted sites was proportionally less than the increase in SRP (+106\%), and as such the sediments here had greater capacity to absorb more SRP before they reached equilibrium (assuming the sediment was not already saturated with P). Similar results have previously been reported for the River Avon and River Wye, UK (Jarvie et al. 2005), and they reveal the sediments downstream of STWs were better able to buffer the river against increases in dissolved SRP released in sewage effluent.

The buffering potential is confirmed by a linear regression model of SRP concentration against $\mathrm{EPC}_{0}$ for all data points (Fig. 6a). This reveals a weak $\left(R^{2}=0.20\right)$ but significant $(p<0.05)$ positive correlation, with a gradient $<1$ indicating that the riverbed sediments were not in equilibrium with SRP in the overlying water column and therefore had the capacity for sorption when exposed to higher dissolved SRP concentrations. This correlation strengthens further $\left(R^{2}=0.50\right)$ when considering only the mean $\mathrm{EPC}_{0}$ and SRP values for each site (Fig. 6b), with
Fig. 4 Average a river watersoluble reactive phosphorus concentrations and $\mathbf{b}$ riverbed sediment $\mathrm{EPC}_{0}$ values for ten sampling sites on the River Wensum with and without sewage treatment works (STWs). Error bars represent one standard error
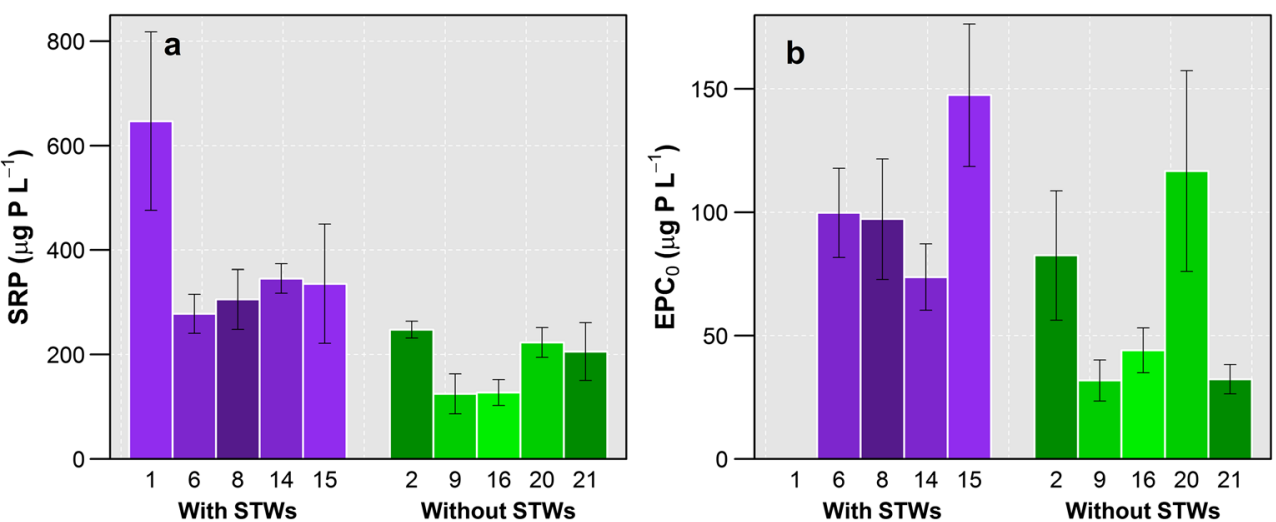
Fig. 5 Uptake and release potential for soluble reactive phosphorus of River Wensum bed sediments for sites a with or without STWs and $\mathbf{b}$ during different months. Points below the $1: 1$ equilibrium line indicate potential SRP uptake by riverbed sediments, whilst points above the equilibrium indicate potential SRP release into the overlying water column

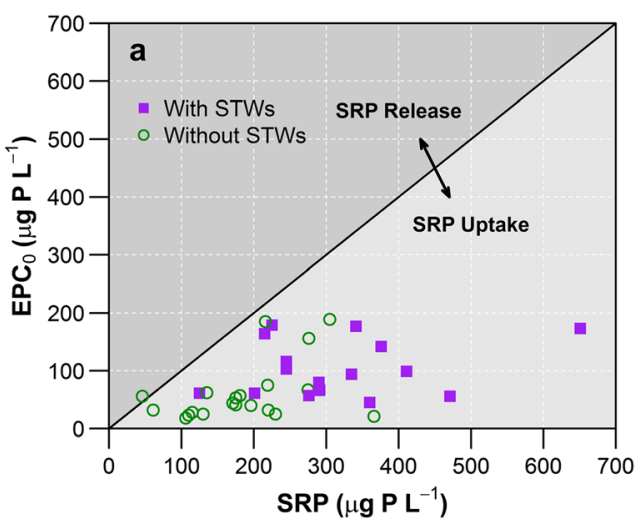

this positive relationship revealing that riverbed sediments generally have higher $\mathrm{P}$ concentrations at sites exposed to higher dissolved SRP concentrations downstream of STWs.

The fact that riverbed sediments were acting as sinks for SRP across the catchment, regardless of whether the site is influenced by a STW, indicates there are significant $\mathrm{P}$ inputs from other sources elevating dissolved SRP in the water column. Given the dominance of intensive agricultural land across the catchment, this is most likely due to diffuse pollution from phosphate fertilisers, with a previous study in the River Wensum catchment revealing 1-2\% of total annual P fertiliser application is lost into the river network (Outram et al. 2016).

Ultimately, the ability of sediments to sorb $\mathrm{P}$ is determined by the chemical composition of the catchment bedrock and superficial geology which whether to produce the soils and sediments that determine the natural background $\mathrm{P}$ buffering capacity (Walling et al. 2001; van der Perk et al. 2007; Ballantine et al. 2008). As such, it might be expected that $\mathrm{EPC}_{0}$ values in the Wensum catchment would be higher in areas where fine glacial till is the dominant superficial deposit and values would be lower in areas covered with coarse sands and gravels. This is because $\mathrm{P}$ sorption can only occur across the water-sediment interface and, as such, the specific surface area (SSA) of sediments strongly influences the rates of surface reactions and the ability of sediments to adsorb P (Evans et al. 2004; Rawlins et al. 2010). Sediments dominated by fine-grained particles have higher SSAs and tend to contain greater concentrations of clay minerals and metal oxyhydroxide complexes to which $\mathrm{P}$ has a high affinity, thus enhancing sorption rates (Hartikainen et al. 2010; Cooper et al. 2015). However, here $\mathrm{EPC}_{0}$ values displayed no obvious relationship with either the bedrock/superficial geology (Fig. S1, Electronic Supplementary Material) or the soil type (Fig. S2, Electronic Supplementary Material) present across the catchment, with instead the presence or absence of STWs remaining the dominant discriminator of $\mathrm{EPC}_{0}$ values.

\subsection{Temporal $\mathbf{P}$ dynamics}

Over the duration of the study, mean SRP concentrations for all sites were highest in September $\left(363 \mu \mathrm{g} \mathrm{P} \mathrm{L}{ }^{-1} ; \sigma=\right.$ $\left.173 \mu \mathrm{g} \mathrm{P} \mathrm{L}^{-1}\right)$, followed by October $\left(299 \mu \mathrm{g} \mathrm{P} \mathrm{L}{ }^{-1} ; \sigma=\right.$ $\left.309 \mu \mathrm{g} \mathrm{P} \mathrm{L}^{-1}\right)$, July $\left(255 \mu \mathrm{g} \mathrm{P} \mathrm{L}^{-1} ; \sigma=82 \mu \mathrm{g} \mathrm{P} \mathrm{L}{ }^{-1}\right)$ and August (248 $\mu \mathrm{g} \mathrm{P} \mathrm{L}{ }^{-1} ; \sigma=127 \mu g \mathrm{P} \mathrm{L}^{-1}$ ) (Table 1). September also yielded the highest mean SRP concentrations when considering sites with $\left(496 \mu \mathrm{g} \mathrm{P} \mathrm{L}^{-1}\right)$ and without (229 $\mu \mathrm{g} \mathrm{P} \mathrm{L}^{-1}$ ) STW influence, thus indicating these September peaks were related to external climatic factors rather than fluctuations in effluent discharge. Heavy rainfall (35 $\mathrm{mm})$ in the days preceding the September sampling
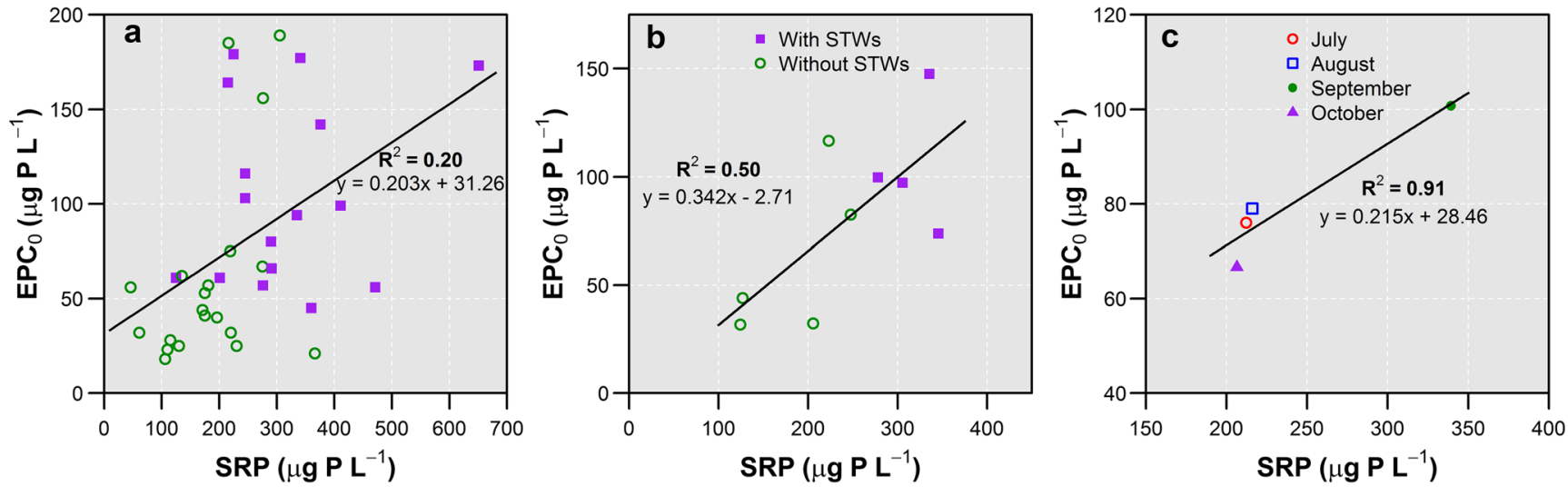

Fig. 6 Correlation plots of soluble reactive phosphorus concentration against riverbed sediment $\mathrm{EPC}_{0}$ for $\mathbf{a}$ all data, $\mathbf{b}$ site means and $\mathbf{c}$ monthly means 
resulted in higher river flows (14\% above the 1969-2016 average for this date) than observed during July (9\% below average), August (14\% below average) and October (40\% below average) when baseflow conditions prevailed. Under these higher September flows, dilutions in SRP concentration would typically be expected if the majority of $\mathrm{P}$ originated from continuous point source STW release. The concentration increases observed here therefore strongly suggests diffuse $\mathrm{P}$ from agriculture was a more important source of $\mathrm{P}$ input into the River Wensum at the time of the September sampling due to precipitation-induced soil erosion and flushing of $P$ sources from across the wider catchment (Quinton et al. 2001). This is supported by previous studies which have shown up to $70 \%$ of annual riverine $\mathrm{P}$ load is transported from arable dominated sub-catchments of the River Wensum during storm events at mean rates of 0.1-0.2 kg P ha ${ }^{-1}$ (Outram et al. 2014; Outram et al. 2016). It is also likely that the elevated September discharge initiated the remobilisation of P-rich fines deposited on the riverbed during intervening periods of low flow when sediment and $\mathrm{P}$ retention times would have been greater.

Mean $\mathrm{EPC}_{0}$ values of the riverbed sediments were similarly highest during September at sites with $\left(118 \mu \mathrm{g} \mathrm{P} \mathrm{L}^{-1} ; \sigma=\right.$ $\left.51 \mu \mathrm{g} \mathrm{P} \mathrm{L}^{-1}\right)$ and without $\left(70 \mu \mathrm{g} \mathrm{P} \mathrm{L}^{-1} ; \sigma=79 \mu \mathrm{g} \mathrm{L} \mathrm{L}^{-1}\right.$ ) STWs, revealing elevated levels of particulate $\mathrm{P}$ on the riverbed at some, but not all, sites at this time. This probably indicates the deposition of P-rich soil eroded from the surrounding agricultural land during this heavy rainfall event. Despite this increase, the mean residual concentration in September $\left(239 \mu \mathrm{g} \mathrm{P} \mathrm{L}^{-1}\right)$ was significantly $(p<0.05)$ larger than for the other 3 months (136$140 \mu \mathrm{g} \mathrm{P} \mathrm{L}^{-1}$ ), indicating greater potential to buffer the river against the higher dissolved SRP concentrations (Fig. 5b). The lowest $\mathrm{EPC}_{0}$ values were recorded in October for sites with $\left(90 \mu \mathrm{g} \mathrm{P} \mathrm{L}^{-1} ; \sigma=58 \mu \mathrm{g} \mathrm{P} \mathrm{L}^{-1}\right)$ and without $\left(43 \mu \mathrm{g} \mathrm{P} \mathrm{L}^{-1}\right.$; $\sigma=10 \mu \mathrm{g} \mathrm{P} \mathrm{L}^{-1}$ ) STWs. The relationship between the average monthly SRP concentrations and $\mathrm{EPC}_{0}$ values reveals a strong $\left(R^{2}=0.91\right)$ positive correlation (Fig. 6c), albeit with limited data points, with an SRP:EPC ${ }_{0}$ ratio of 5:1 indicating sediment during all months was acting as a net sink for SRP.

\subsection{Significance and implications}

Despite being conducted over just a 4-month period, the results presented here clearly demonstrate riverbed sediments are acting as sinks for SRP across the River Wensum catchment, regardless of the presence or absence of STWs. However, although the $\mathrm{EPC}_{0}$ values of riverbed sediments have been shown to increase with an increase in SRP, the elevated concentrations of SRP downstream of STWs clearly demonstrate that the sediments have insufficient $\mathrm{P}$ sorption capacity to be able to fully buffer the river against effluent discharge. This is due to the combination of higher effluent contributions to river flow under baseflow conditions and suboptimal contact time at the water-sediment interface for the river to reach equilibrium conditions with respect to $\mathrm{P}$ sorption (Jarvie et al. 2005). If P cycling cannot self-regulate the river system to lower dissolved SRP concentrations below ecologically damaging levels, then it is imperative that future $P$ supply to the river is reduced to prevent eutrophication causing further ecosystem degradation.

Furthermore, sections of the River Wensum are currently being restored through actions including weir removal, reinitiating meanders, creating pool and riffle sequences, and gravel jetting to remove excess sediment, with the ultimate aim of regaining the original features of a lowland chalk river (e.g. faster heterogeneous flow with exposed gravel beds). If successful, these alterations will see a change from sedimentdominated to gravel-dominated riverbeds across the catchment. As gravel has reduced affinity to adsorb P than silt, the ability of bed sediments to buffer the river against highSRP concentrations released by STWs could be diminished and $\mathrm{P}$ concentrations in the overlying water may increase (Stone et al. 1995; Jarvie et al. 2005). This means that changes to restore the original ecosystem of the River Wensum could in fact lead to more widespread eutrophication problems in the short-medium term unless accompanied by mitigation measures to reduce $\mathrm{P}$ loading that would enable the river to reach a new equilibrium at lower $P$ levels.

\section{Conclusions}

Through the analysis of water and riverbed sediment samples collected across the River Wensum catchment, this research demonstrates that STWs significantly impact upon the P dynamics of this lowland calcareous river system. The mean dissolved SRP concentration recorded downstream of STWs was double that observed at sites unaffected by effluent discharges, whilst the mean $\mathrm{EPC}_{0}$ value of bed sediments was also 70\% higher. Irrespective of STW influence and spatial and temporal variability in sample collection, riverbed sediments were almost always acting as sinks for SRP from the overlying water column, with SRP concentrations consistently greater than the sediment $\mathrm{EPC}_{0}$ values. This was particularly true downstream of STWs where sediments displayed greater potential to buffer the river against increases in dissolved SRP released in sewage effluent. With riverbed sediments consistently acting as SRP sinks, these results indicate significant $\mathrm{P}$ inputs from other sources, most likely diffuse fertiliser pollution from agriculture, particularly during higher flow flushing events. Despite riverbed sediments acting as sinks, elevated SRP concentrations downstream of STWs evidently demonstrate the sediments have insufficient $\mathrm{P}$ sorption capacity to fully buffer the river against effluent discharges. As such, SRP concentrations across the catchment continue to exceed recommended standard for good chemical status, emphasising the environmental requirement for advanced P-stripping 
technologies to be installed at smaller STWs across the catchment to minimise $\mathrm{P}$ loading.

Acknowledgements Emma Hooper and Lynda Turner are thanked for providing laboratory assistance and Gilla Sünnenberg for providing the GIS datasets. We are grateful to two anonymous reviewers whose contrastive comments helped improve this manuscript.

Funding information This research was financially supported by the School of Environmental Sciences, University of East Anglia.

Open Access This article is distributed under the terms of the Creative Commons Attribution 4.0 International License (http:// creativecommons.org/licenses/by/4.0/), which permits unrestricted use, distribution, and reproduction in any medium, provided you give appropriate credit to the original author(s) and the source, provide a link to the Creative Commons license, and indicate if changes were made.

\section{References}

Ballantine DJ, Walling DE, Collins AL, Leeks GJL (2008) The phosphorus content of fluvial suspended sediment in three lowland groundwater-dominated catchments. J Hydrol 357(1-2):140-151. https://doi.org/10.1016/j.jhydrol.2008.05.011

Bewes V, Codling I, Davey A, Withers PJ (2012) Review of phosphorus pollution in Anglian River Basin district. In: Agency E (ed) Environment Agency, Horizon House, Bristol, pp 166

Bowes MJ, Ings NL, McCall SJ, Warwick A, Barrett C, Wickham HD, Harman SA, Armstrong LK, Scarlett PM, Roberts C, Lehmann K, Singer AC (2012) Nutrient and light limitation of periphyton in the River Thames: implications for catchment management. Sci Total Environ 434:201-212. https://doi.org/10.1016/j.scitotenv.2011.09. 082

CEH (2018) National river flow archive. http://nrfa.ceh.ac.uk/data/ station/info/34014. Accessed 25 Jan 2018

Cooper DM, House WA, May L, Gannon B (2002) The phosphorus budget of the Thame catchment, Oxfordshire, UK: 1. Mass balance. Sci Total Environ 282-283:233-251. https://doi.org/10.1016/ S0048-9697(01)00953-6

Cooper RJ, Rawlins BG, Krueger T, Leze B, Hiscock KM, Pedentchouk $\mathrm{N}$ (2015) Contrasting controls on the phosphorus concentration of suspended particulate matter under baseflow and storm event conditions in agricultural headwater streams. Sci Total Environ 533:4959. https://doi.org/10.1016/j.scitotenv.2015.06.113

Cordell D, Drangert J-O, White S (2009) The story of phosphorus: global food security and food for thought. Glob Environ Change 19(2): 292-305. https://doi.org/10.1016/j.gloenvcha.2008.10.009

Demars BO, Harper DM (2005) Water column and sediment phosphorus in a calcareous lowland river and their differential response to point source control measures. Water Air Soil Pollut 167(1-4):273-293. https://doi.org/10.1007/s11270-005-8862-7

Demars BO, Harper DM, Pitt JA, Slaughter R (2005) Impact of phosphorus control measures on in-river phosphorus retention associated with point source pollution. Hydro Earth Syst Sci 9(1/2):43-55. https://doi.org/10.5194/hess-9-43-2005

Edwards AC, Withers PJA (2008) Transport and delivery of suspended solids, nitrogen and phosphorus from various sources to freshwaters in the UK. J Hydrol 350(3-4):144-153. https://doi.org/10.1016/j. jhydrol.2007.10.053

Evans DJ, Johnes PJ, Lawrence DS (2004) Physico-chemical controls on phosphorus cycling in two lowland streams. Part 2-the sediment phase. Sci Total Environ 329(1-3):165-182. https://doi.org/10.1016/ j.scitotenv.2004.02.023

Evans R (2012) Reconnaissance surveys to assess sources of diffuse pollution in rural catchments in East Anglia, eastern England-implications for policy. Water Environ J 26(2):200-211. https://doi. org/10.1111/j.1747-6593.2011.00277.x

Hartikainen H, Rasa K, Withers PJA (2010) Phosphorus exchange properties of European soils and sediments derived from them. Eur J Soil Sci 61(6):1033-1042. https://doi.org/10.1111/j.1365-2389.2010. 01295.x

Hilton J, O'Hare M, Bowes MJ, Jones JI (2006) How green is my river? A new paradigm of eutrophication in rivers. Sci Total Environ 365(13):66-83. https://doi.org/10.1016/j.scitotenv.2006.02.055

Hiscock KM, Dennis PF, Saynor PR, Thomas MO (1996) Hydrochemical and stable isotope evidence for the extent and nature of the effective chalk aquifer of north Norfolk, UK. J Hydrol 180(1-4):79-107. https://doi.org/10.1016/0022-1694(95)02895-1

House WA, Denison FH, Armitage PD (1995) Comparison of the uptake of inorganic phosphorus to a suspended and stream bed-sediment. Water Res 29(3):767-779. https://doi.org/10.1016/0043-1354(94) 00237-2

House WA, Denison FH (2000) Factors influencing the measurement of equilibrium phosphate concentrations in river sediments. Water Res 34(4):1187-1200. https://doi.org/10.1016/S0043-1354(99)00249-3

House WA, Denison FH (2002) Total phosphorus content of river sediments in relationship to calcium, iron and organic matter concentrations. Sci Total Environ 282-283:341-351. https://doi.org/10.1016/ S0048-9697(01)00923-8

Jarvie HP, Jürgens MD, Williams RJ, Neal C, Davies JJL, Barrett C, White J (2005) Role of river bed sediments as sources and sinks of phosphorus across two major eutrophic UK river basins: the Hampshire Avon and Herefordshire Wye. J Hydrol 304(1-4):5174. https://doi.org/10.1016/j.jhydrol.2004.10.002

Jarvie HP, Neal C, Withers PJ (2006) Sewage-effluent phosphorus: a greater risk to river eutrophication than agricultural phosphorus? Sci Total Environ 360(1-3):246-253. https://doi.org/10.1016/j. scitotenv.2005.08.038

Jarive HP, Smith DR, Norton LR, Edwards FK, Bowes MJ, King SM, Scarlett P, Davies S, Dils RM, Bachiller-Jareno N (2018) Phosphorus and nitrogen limitation and impairment of headwater streams relative to rivers in Great Britain: a national perspective on eutrophication. Sci Total Environ 621:849-862. https://doi.org/10. 1016/j.scitotenv.2017.11.128

Lewis MA (2014) Borehole drilling and sampling in the Wensum Demonstration Test catchment. British Geological Survey commissioned report CR/11/162, 52 pp

Met Office (2017) UK Climate Averages. https://www.metoffice.gov.uk/ public/weather/climate/u12unggmv. Accessed: 23 January 2018

Moss B, Balls H, Booker I, Manson K, Timms M (1988) Problems in the construction of a nutrient budget for the river bure and its broads (Norfolk) prior to its restoration from eutrophication. In: Round FE (ed) Algae and the aquatic environment, biopress, Bristol, pp 327 353

Natural England (2015) River Wensum SSSI- exemplar diffuse water pollution plan and action plan. In: England N (ed), pp 109

Neal C, Jarvie HP, Neal M, Love AJ, Hill L, Wickham H (2005) Water quality of treated sewage effluent in a rural area of the upper Thames Basin, Southern England, and the impacts of such effluents on riverine phosphorus concentrations. J Hydrol 304(1-4):103-117. https://doi.org/10.1016/j.jhydrol.2004.07.025

Outram FN, Lloyd CEM, Jonczyk J, Benskin C, Grant F, Perks MT, Deasy C, Burke SP, Collins AL, Freer J, Haygarth PM, Hiscock KM, Johnes PJ, Lovett AL (2014) High-frequency monitoring of nitrogen and phosphorus response in three rural catchments to the end of the 2011-2012 drought in England. Hydrol Earth Syst Sci 18(9):3429-3448. https://doi.org/10.5194/hess-18-3429-2014 
Outram FN, Cooper RJ, Sünnenberg G, Hiscock KM, Lovett AA (2016) Antecedent conditions, hydrological connectivity and anthropogenic inputs: factors affecting nitrate and phosphorus transfers to agricultural headwater streams. Sci Total Environ 545-546:184-199. https://doi.org/10.1016/j.scitotenv.2015.12.025

Palmer-Felgate EJ, Jarvie HP, Withers PJA, Mortimer RJG, Krom MD (2009) Stream-bed phosphorus in paired catchments with different agricultural land use intensity. Agric Ecosyst Environ 134(1-2):5366. https://doi.org/10.1016/j.agee.2009.05.014

Pretty JN, Mason CF, Nedwell DB, Hine RE, Leaf S, Dils R (2003) Environmental costs of freshwater eutrophication in England and Wales. Environ Sci Technol 37(2):201-208. https://doi.org/10. $1021 / \mathrm{es} 020793 \mathrm{k}$

Quinton J, Catt JA, Hess TM (2001) The selective removal of phosphorus from soil: is event size important? J Environ Qual 30(2):538-545. https://doi.org/10.2134/jeq2001.302538x

Rawlins BG, Turner G, Mounteney I, Wildman G (2010) Estimating specific surface area of fine stream bed sediments from geochemistry. Appl Geochem 25(9):1291-1300. https://doi.org/10.1016/j. apgeochem.2010.05.009

Sear DA, Newson M, Old JC, Hill C (2006) Geomorphological appraisal of the River Wensum special area of conservation. In: nature $\mathrm{E}$ (Hrsg.), Northminster House, Peterborough, pp 47

Smith VH, Tilman GD, Nekola JC (1999) Eutrophication: impacts of excess nutrient inputs on freshwater,marine, and terrestrial ecosystems. Environ Pollut 100(1-3):179-196. https://doi.org/10. 1016/S0269-7491(99)00091-3

Stone M, Mulamoottil G, Logan L (1995) Grain size distribution effects on phosphate sorption by fluvial sediment: implications for modelling sediment-phosphate transport. Hydrol Science J 40(1):67-81. https://doi.org/10.1080/02626669509491391

van der Perk M, Owens PN, Deeks LK, Rawlins BG, Haygarth PM, Beven KJ (2007) Controls on catchment-scale patterns of phosphorus in soil, streambed sediment, and stream water. J Environ Qual 36(3):694-708. https://doi.org/10.2134/jeq2006.0175

Walling DE, Russell MA, Webb BW (2001) Controls on the nutrient content of suspended sediment transported by British rivers. Sci Total Environ 266(1-3):113-123. https://doi.org/10.1016/S00489697(00)00746-4

Wang Q, Li Y (2010) Phosphorus adsorption and desorption behavior on sediments of different origins. J Soils Sediments 10(6):1159-1173. https://doi.org/10.1007/s11368-010-0211-9

Withers PJ, Jarvie HP (2008) Delivery and cycling of phosphorus in rivers: a review. Sci Total Environ 400(1-3):379-395. https://doi. org/10.1016/j.scitotenv.2008.08.002

Zhang J-Z, Huang X-L (2007) Relative importance of solid-phase phosphorus and iron on the sorption behavior of sediments. Environ Sci Technol 41(8):2789-2795. https://doi.org/10.1021/es061836q 